\title{
Factors Influencing Engagement on Official Facebook Page of Mobile Operator Companies in Indonesia
}

\author{
Indrawati and Mamun Sumarna
}

\begin{abstract}
The number of internet users and social media in Indonesia is very big and the trend is still rising. Facebook is a social media platform most widely used in Indonesia. Facebook provides Facebook Page for brands, companies and organizations who want to communicate and build engagement with customers. This phenomenon is an opportunity for companies to use the Facebook Page as a marketing communication channel to building communication and increase engagement with customers. With Sequential Explanatory Mixed Methods approach, this study answers the question of what content type, media type, and posting time that generates the highest engagement on Facebook Page, as well as answers the question of what programs or tactics used by the company to increase engagement on Facebook Page. The study found that content type of information generates highest engagement, content type of remuneration generates most comment, and contents posted on weekdays (MondayFriday) generate highest engagement. Study also found that investing in Facebook ads is good tactic to improve content reach and increase engagement on Facebook Page.
\end{abstract}

Index Terms-Social media, Facebook page, customer engagement, marketing communication, social media marketing.

\section{INTRODUCTION}

Indonesia is the fourth most populous country in the world with population reached 259.1 million in 2015. Indonesia is also a country with large internet users, reaching 88.1 million internet accesses, or approximately $34 \%$ of the total population [1]. Internet penetration in Indonesia is still below the average internet penetration in the world (46\%). It is even still below internet penetration in some ASEAN countries such as Philippines (46\%), Vietnam (50\%), Thailand (56\%), Malaysia (68\%), and Singapore $(82 \%)$. It means that the number of internet users in Indonesia still has the opportunity to increase. Social media users in Indonesia are also very huge, reaching 79 million active social media accounts used [1]. This figure shows that almost all internet users in Indonesia are also social media users. If internet users grow, social media users in Indonesia will likely grow too. Facebook is the most widely used social media platform in Indonesia, reaching approximately 39 million accounts, more than Google+, Twitter, Instagram, and Pinterest [1]. This is a great opportunity for companies to communicate and build engagement with customers through Facebook.

Manuscript received October 9, 2017; revised Decmber 13, 2017.

Indrawati and Mamun Sumarna are with Faculty of Economics \& Business at Telkom University, Bandung, Indonesia (e-mail: indrawati@telkomuniversity.ac.id,msumarna@gmail.com).
Facebook provides a feature called Facebook Page that can be used by brand owners, business institutions, organizations, and public figures to present on Facebook and build communication with Facebook users. Having a Facebook account Page, companies can build engagement with consumers by posting content in the form of status, image, video, and link to Facebook page. Companies can also build engagement by offering virtual gifts, contests, and company promotions [2]. In addition, a Facebook Page also has a variety of useful features for companies such as analytics and report that can be used by companies as a basis to advertise on Facebook [3]. There are several strategies and tactics to consider by the company to be successful in utilizing Facebook Page, among which is the selection of the content and timing of posting content [3]. Everything posted by a company to a Facebook Page is a content, and has the opportunity to increase engagement with customers.

This study explores the factors that may affect engagement on a Facebook Page, by investigating which content types, media types, posting day and posting time that can generate highest engagement, and what programs or tactics can be used to increase engagement on Facebook Page. The object of this research are five official Facebook Page accounts belong to five mobile operator companies in Indonesia, i.e. PT Telekomunikasi Seluler, PT Indosat Tbk, PT XL Axiata Tbk, PT Hutchison Tri Indonesia, and PT Smartfren Tbk.

\section{BASIC THEORY AND METHODOLOGY}

\section{A. Marketing Comunication, Social Media and Engagement}

Marketing communications is a means used by company to inform, persuade and remind consumers about the brands and products they sell. Marketing communications is a means for companies to build dialogue and relationships with consumers [4]. Marketing communication can be done through a marketing communications mix, namely advertising, sales promotion, events and experiences, public relations and publicity, direct marketing, interactive marketing, word-of-mouth marketing, and personal selling.

Social media is defined as "the many relatively inexpensive and widely accessible electronic tools that enable anyone to publish and access information, collaborate on a common effort, or build relationships" [5]. Social media introduces changes in terms of communication between business institutions, organizations, communities, and individuals [6]. Castronovo and Huang made the classification of the various social media platforms, namely Chat Rooms, Blogs, YouTube, Facebook, LinkedIn, Twitter, Google Wave and Four Square [7]. Mangold and Faulds mention that there are two social media's roles in relation to 
marketing communications. The first role is consistent with the use of social media as traditional Integrated Marketing Communications (IMC) tool, where the company can use social media (Facebook, etc.) to talk to the customers. The second role is a uniqueness of social media, where the social media platforms can be used by consumers to communicate with other consumers [8].

Evan \& KcKee stated there are four phases of engagement to do with consumers through social media, namely consumption, curation, creation, and collaboration [9]. On social media platform Facebook, engagement of consumers on the content posted by the company can be in the form of reaction, comment and share.

\section{B. Framework}

The framework in this study refers to the model of relationship between content posted on Facebook Page and engagement resulted, as proposed by Cvijikj and Michahelles [10]. The modified model is shown in Fig. 1.

As can be seen in Fig. 1, variables used in this study are as follows:

\section{1) Content type}

Content Type is the substance of content posted on Facebook Page. Content type is obtained through coding process. There are three content types i.e Entertainment, Information and Remuneration. Entertainment is entertaining content, not directly related to the product, brand or company, usually in the form of questions and directly asking for a response from consumers. Information is informative content, created to give information about company's products and services, and other useful information for consumers. Remuneration is rewarding content, usually in the form of quizzes, and created to give reward or benefit to consumers.

\section{2) Media type}

Media Type is the format of content posted on Facebook Page. There are four media types i.e. Text (status), Image, Link and Video. Each media type has different level of vividness and interactivity. Vividness is the ability to describe or visualize the message. There are four level of vividness, i.e. no vividness (status), low vividness (picture), medium vividness (url link), and high vividness (video). Interactivity is the level of effort by consumers to get the message from a content. There are two level of interactivity, i.e. no interactivity (status and photo) and high interactivity (link and video).

\section{3) Posting day}

Posting Day is the day a content posted to Facebook Page, either Work Day (Monday to Friday) or Week End (Saturday and Sunday).

\section{4) Posting time}

Posting Time is the time a content posted to Facebook Page. Peak Hours is when content posted between 16.00 in the afternoon and 04.00 in the morning. Non Peak Hours is content posted from 04.00 to 16.00 .

\section{5) Engagement}

Engagement is the response from consumers to content on Facebook Page. There are four engagement variables measured, i.e. Reactions, Comments, Shares, and Interaction Duration. Interaction Duration is total time from content posted to last comment resulted.

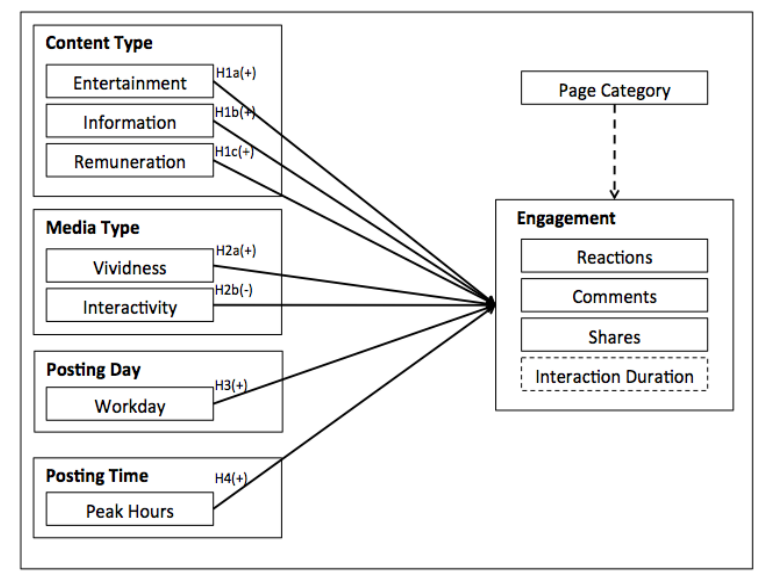

Fig. 1. Research framework.

Page Category in Fig. 1 is the category of company that has Facebook page. In this study, it is Telecommunication.

The hypotheses proposed as shown in Fig. 1 are as follows:

1. H1a(+): Content with type of Entertainment generates highest engagement.

2. H1b(+): Content with type of Information generates lower engagement than Entertainment, but generates higher engagement than other contents.

3. H1c(+): Content with type of Remuneration generates lower engagement than Information, but generate higher engagement than other contents.

4. H2a(+): The higher level of vividness of a content, the higher engagement resulted.

5. H2b(-): The higher level of interactivity of a content, the lower engagement resulted.

6. H3(+): Content posted on week days generates higher engagement.

7. H4(+): Content posted on peak hours generates higher engagement.

\section{Methodology}

The method used in this research is Explanatory Sequential Mixed Methods. This research is verificative, to test hypotheses and model of the relation between content posted and engagement resulted. This research is also comparative, to compare content posted and engagement generated on the official Facebook Page of five mobile operator companies in Indonesia. This research is also exploratory, to explore programs or tactics used to increase engagement on company Facebook Page. Population in this study is contents posted on five official Facebook Page accounts of five mobile operator companies in Indonesia. Sample used in this study is contents posted on Facebook Page in the period from June 2016 to November 2016. Quantitative data is collected by visiting five Facebook Page accounts, reading company's annual report, and searching for data from other available sources on the internet. Content posted on Facebook Page is acquired using Facebook Graph API.

Qualitative data is acquired by interviewing two companies owning and managing Facebook Page accounts researched. The first one is company whose Facebook Page has highest engagement (resulted from quantitative data analysis). The second one is company that has the highest mobile subscribers, i.e. Telkomsel. The Interviews were 
conducted in semi-structured format, started by asking questions based on variables of quantitative research model and followed by other questions to obtain information about programs or tactics used by company to increase engagement on Facebook Page.

\section{RESUlt AND DisCUSSION}

\section{A. Content Posted on Facebook Page}

Facebook Page contents collected and analyzed in this research are content posted from June 1, 2016 to November 30, 2016 on Facebook Page accounts of five mobile operator companies in Indonesia. There are 2,908 posts collected, with Telkomsel posted most contents, i.e. 1,476 contents or average of 246 posts per month, more than 8 posts per day, and XL Axiata posted least contents, i.e. 227 contents or average of 38 posts per month, below 2 posts per day.

\section{B. Average Engagement per Post}

In this research, engagement is dependent variable, consists of Reactions, Comments, Shares, and Interaction Duration. Total reactions, comments, and shares are obtained from Facebook Graph API script. Interaction Duration is obtained from subtracting time of last comment from time of content published. Average Engagement Per Post (AEPP) is total engagement devided by total content posted, as shown in Table I. We can see that, contents posted by the administrator on Smartfren Facebook Page generate highest engagements, more than 7,000 average engagements per post, followed by XL with nearly 3,300 AEPP, then Tri Indonesia with more than 2,500 AEPP, Indosat with more than 1,500 AEPP, and Telkomsel with less than 415 AEPP. In other words, Smartfren Facebook Page generates the highest AEPP, with engagements in the form of reaction reached more than 53 times of engagements in the form of comment, and engagement in the form of comment reached more than 11 times engagement in the form of share.

\begin{tabular}{|c|c|c|c|c|c|c|}
\hline & 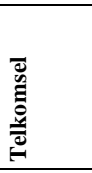 & $\begin{array}{l}\overrightarrow{\tilde{y}} \\
\vec{g} \\
\underline{\Xi}\end{array}$ & : & $\begin{array}{l}\frac{\pi}{\frac{\pi}{x}} \\
\frac{\pi}{4} \\
\frac{1}{x}\end{array}$ & 氞 & 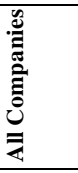 \\
\hline $\begin{array}{l}\text { Average Reactions } \\
\text { Per Post }\end{array}$ & 355,9 & $1.535,3$ & $2.490,2$ & $3.213,0$ & $6.976,5$ & $1.940,8$ \\
\hline $\begin{array}{l}\text { Average Comments } \\
\text { Per Post }\end{array}$ & 53,0 & 43,6 & 38,2 & 86,2 & 129,9 & 63,0 \\
\hline $\begin{array}{l}\text { Average Shares } \\
\text { Per Post }\end{array}$ & 8,2 & 6,2 & 8,3 & 10,1 & 11,8 & 8,7 \\
\hline $\begin{array}{l}\text { Average Engagements } \\
\text { Per Post }\end{array}$ & 414,9 & $1.535,9$ & $2.522,4$ & $3.294,5$ & $7.064,6$ & $1.994,3$ \\
\hline $\begin{array}{l}\text { Average Interaction } \\
\text { Duration }\end{array}$ & 5,4 & 10,6 & 8,3 & 17,6 & 20,4 & 9,5 \\
\hline
\end{tabular}

\section{Hypothesis Testing}

To test the research hypothesis, researchers calculate AEPP for each independent variable in the research model as shown in Table II. The authors then tested the hypothesis by comparing the AEPP data for each variable. The test results for all the hypotheses used in this study are shown in Table III.

\begin{tabular}{|c|c|c|c|c|}
\hline & Reactions & Comments & Shares & $\begin{array}{l}\text { Interaction } \\
\text { Duration } \\
\text { (days) }\end{array}$ \\
\hline \multicolumn{5}{|l|}{ Content Type } \\
\hline Entertainment & $1.083,2$ & 50,8 & 7,7 & 8,9 \\
\hline Information & $2.667,0$ & 51,9 & 7,8 & 10,1 \\
\hline Remuneration & $2.548,7$ & 154,1 & 15,6 & 8,3 \\
\hline Other & 304,2 & 42,7 & 7,0 & 9,4 \\
\hline \multicolumn{5}{|l|}{ Media Type } \\
\hline Photo & $1.574,0$ & 63,2 & 8,1 & 8,7 \\
\hline Status & 409,9 & 119,4 & 15,0 & 18,4 \\
\hline Video & $1.420,2$ & 35,8 & 10,1 & 10,7 \\
\hline Link & $14.251,2$ & 99,7 & 10,5 & 16,0 \\
\hline Event & - & - & - & - \\
\hline \multicolumn{5}{|l|}{ Posting Day } \\
\hline Work Day & $2.413,8$ & 65,8 & 9,4 & 10,0 \\
\hline Week End & 583,3 & 54,8 & 6,4 & 8,3 \\
\hline \multicolumn{5}{|l|}{ Posting Time } \\
\hline Peak Hour & $3.460,9$ & 73,4 & 9,7 & 10,6 \\
\hline Low Hour & $1.118,5$ & 57,4 & 8,1 & 9,0 \\
\hline
\end{tabular}

TABLE III: HYPHOTESIS TESTING

\begin{tabular}{|c|c|c|c|c|}
\hline \multirow{2}{*}{ Hypotheses } & \multicolumn{4}{|c|}{ Results } \\
\hline & Reactions & Comments & Shares & $\begin{array}{l}\text { Interaction } \\
\text { Duration }\end{array}$ \\
\hline $\begin{array}{l}\text { H1a(+): Content with type } \\
\text { of Entertainment generates } \\
\text { highest engagement }\end{array}$ & $\begin{array}{l}\text { Not } \\
\text { Supported }\end{array}$ & $\begin{array}{l}\text { Not } \\
\text { Supported }\end{array}$ & \begin{tabular}{|l} 
Not \\
Supported
\end{tabular} & $\begin{array}{l}\text { Not } \\
\text { Supported }\end{array}$ \\
\hline $\begin{array}{l}\text { H1b(+): Content with type } \\
\text { of Information generates } \\
\text { lower engagement than } \\
\text { Entertainment, but } \\
\text { generates higher } \\
\text { engagement than other } \\
\text { contents }\end{array}$ & \begin{tabular}{|l} 
Partially \\
Supported
\end{tabular} & \begin{tabular}{|l|} 
Not \\
Supported
\end{tabular} & \begin{tabular}{|l|} 
Not \\
Supported
\end{tabular} & $\begin{array}{l}\text { Partially } \\
\text { Supported }\end{array}$ \\
\hline $\begin{array}{l}\text { H1c }(+) \text { : Content with type } \\
\text { of Remuneration generates } \\
\text { lower engagement than } \\
\text { Information, but generate } \\
\text { higher engagement than } \\
\text { other contents }\end{array}$ & \begin{tabular}{|l} 
Partially \\
Supported
\end{tabular} & $\begin{array}{l}\text { Partially } \\
\text { Supported }\end{array}$ & \begin{tabular}{|l|} 
Partially \\
Supported
\end{tabular} & \begin{tabular}{|l} 
Partially \\
Supported
\end{tabular} \\
\hline $\begin{array}{l}\mathrm{H} 2 \mathrm{a}(+) \text { : The higher level of } \\
\text { vividness of a content, the } \\
\text { higher engagement resulted }\end{array}$ & \begin{tabular}{|l|} 
Partially \\
Supported
\end{tabular} & \begin{tabular}{|l|} 
Not \\
Supported
\end{tabular} & \begin{tabular}{|l|} 
Not \\
Supported
\end{tabular} & \begin{tabular}{|l|} 
Not \\
Supported
\end{tabular} \\
\hline $\begin{array}{l}\mathrm{H} 2 \mathrm{~b}(-) \text { : The higher level of } \\
\text { interactivity of a content, } \\
\text { the lower engagement } \\
\text { resulted }\end{array}$ & $\begin{array}{l}\text { Not } \\
\text { Supported }\end{array}$ & Supported & $\begin{array}{l}\text { Partially } \\
\text { Supported }\end{array}$ & \begin{tabular}{|l} 
Partially \\
Supported
\end{tabular} \\
\hline $\begin{array}{l}\mathrm{H} 3(+) \text { : Content posted on } \\
\text { week days generates higher } \\
\text { engagement }\end{array}$ & Supported & Supported & Supported & Supported \\
\hline $\begin{array}{l}\mathrm{H} 4(+) \text { : Content posted on } \\
\text { peak hours generates higher } \\
\text { engagement }\end{array}$ & Supported & Supported & Supported & Supported \\
\hline
\end{tabular}

\section{Discussion}

\section{1) Management of company Facebook page}

In terms of goal to create and manage a Facebook Page, companies interviewed treat Facebook Page account as one of company digital assets that has to be managed and developed. They use Facebook Page as marketing communication channel and as customer service channel. Combining both functions into a single platform like this has advantages and disadvantages. The advantage is with one platform will make customers easier to identify Customer Touch Point provided by the company. The disadvantage is company needs more effort to recognize and distinguish engagement resulted through the platform, whether it's a response to content posted by company, or it's a comment, suggestion, or question from consumers not related to content posted by company. To resolve this problem, Telkomsel allows consumers to post content to company Facebook Page, and directing consumers to write complaints 
and questions by creating a post to company Facebook Page, instead of commenting on content posted by company.

Result shows that different content type, media type, posting day and posting time generates different engagements. This suggests companies to do content management and posting time management in order to get maximum engagement. Smartfren and Telkomsel are seriously managing Facebook Page and other social media accounts by forming digital creative and social media management team in company organizational structure. The team has been creating editorial plan in weekly basis to determine what content and when content will be posted on Facebook Page. Smartfren and Telkomsel also hire digital creative agency in producing content to be posted on Facebook Page.

\section{2) Content type of company Facebook page}

In contrast to the results of research conducted by Cvijikj and Michahelles [10] which showed that content with type of entertainment generate highest engagement, this study shows that for Facebook Page of mobile operator companies, content with type of information generates highest engagement. This could be happened because the mobile communication industry is an industry in the field of technology where consumers need a lot of information or education. Content with type of remuneration also produces very high engagement, generating almost same total reactions with content with type of information, and generates highest engagement in form of comment and share, but generates low interaction duration. This happens because consumers like something that offering gifts or benefits. Content with type of remuneration usually offers gifts or benefits if consumers write a comment, so this type of content resulting highest comment. Content in form of a quiz or the like is usually limited by time, so the interaction duration of this content type generate lowest interaction duration compared to other types. For total engagements, i.e. summary of reactions, comments, and shares, content with type of entertainment produces lower engagements than content with type of remuneration and information. Result of this study is different from model proposed by Cvijikj and Michahelles [10] where content type that produces highest engagement is entertainment, followed by information, and remuneration, while the results of this study shows content type that generates highest engagement is information, followed by remuneration, and entertainment

\section{3) Media type of company Facebook page}

Analysis shows that the majority of content posted to Facebook Page of five mobile operator companies are in the type of photo. This is in line with suggestions from the research done by Cvijikj and Michahelles [10] that moderator should posting content in the format of photo to get higher engagement because the photo has higher level of vividness than status but has lower level of interactivity than link and video, so the photo should produce highest engagement. This study indicates different results where the content producing highest engagement is link, followed by photo, video and status. In other words, a link that has high level of interactivity can generate highest engagement. This could be happened because at the time this study conducted, Facebook allows content with type of link can be equipped with photos, so from the point of consumers view, that content appears as a photo, and can consume the content without having to click the links. Referring to the proposed model by Cvijikj and Michahelles [10] it can be hypothesized that compared to level of interactivity, level of vividness has more effects on level of engagement.

\section{4) Posting day and posting time of company Facebook page}

Result shows that for all engagements, content posted on Work Day generates higher engagement than content posted on Week End. For reaction engagement, content posted on week days produces almost fourfold engagement generated by content posted on week end. All five mobile operator companies post more than $70 \%$ contents on week days, even XL Axiata posts more than $80 \%$ contents on week days. Regarding posting time, this research gets same results with the hypothesis that content posted on peak hours generates higher engagement than content posted outside peak hour.

\section{5) Engagement on company Facebook page}

A result show that most engagement resulted is reaction, around tenfold of comment and share. This means that Facebook Page is more effective as a marketing communication channel than as a customer service channel, as shown by total complaint or question by consumers in form of comment is far less than the total reaction as consumers response to content posted by company. Nevertheless treating Facebook Page as customer service channel is also very good for company because company will be easier to find questions or complaints on company Facebook Page, rather than seeking consumer complaints spreading anywhere outside company digital assets.

Telkomsel posted many contents, nearly 250 content per month, or more than 8 posts per day. Authors found that many contents on Telkomsel Facebook Page generate high engagements, but in overall, average engagements per post is very low, lowest than others. Too many content posted could be contributing to the low average engagement per post on Telkomsel Facebook Page. This is in line with the information obtained by author during an interview with Dito of Telkomsel that more content posted could increase churn, which means the content is short-lived, easily replaced by other content, which in turn decreases the average engagement per post.

Smartfren Facebook Page successfully obtained the highest AEPP (Average Engagement Per Post). Authors found that some contents posted on Smartfren Facebook Page generate very high engagements, far higher than other contents. It is because some contents boosted with Facebook ads and generate very high engagements. This is in line with information obtained by authors during an interview with Yuditia of Smartfren who stated that if company manage Facebook Page but did not invest in Facebook ads, the results will not be maximum, because since 2015 Facebook changed the algorithm so content on Facebook Page is not too ofter appear organically in the newsfeed of Facebook users, so the company is directed to buy Facebook ads to get maximum content reach and engagement.

\section{CONCLUSIONS AND RECOMMENDATIONS}

Content type that generates highest engagement on Facebook Page of mobile operator companies in Indonesia 
is information, followed by remuneration and entertainment. Media type that produces highest engagement is link, followed by photo, video, and status. Content posted on weekdays produces highest engagement, and content posted after evening until early morning produces highest engagement. To increase engagement on Facebook Page, Smartfren reduces content posted from 8-10 posts per day to only 3 posts per day. Smartfren also uses Facebook Ads to reach more consumers and generate more engagements. To increase engagement on Facebook Page, Telkomsel responding questions or complaints from consumers as quickly as possible so consumers trusted Telkomsel Facebook Page as a reliable Customer Touch Point. Telkomsel also creates some quizes that requires consumers to posting on Telkomsel Facebook Page, thereby increasing consumer awareness and interaction on Telkomsel Facebook Page.

Companies are advised to stay consistently posting more informative content because it is proven in generating highest engagement. To increase comment engagement, companies are advised to increase content with type of remuneration. Companies are advised not too much posting content to Facebook Page because it can reduce average engagements. Companies are also advised to use Facebook Ads to improve content reach and engagement, and to increase consumer awareness of company Facebook Page. This study is examining Facebook Page of mobile operator companies in Indonesia, to analyze content type, posting time and engagement on content posted by moderator. Subsequent research suggested to examine Facebook Page in other industries, analyzing comments and content posted by consumers, researching Facebook Page as customer touch point or CRM (Customer Relationship Management) tool, and examining Facebook Page as social advertising platform.

\section{REFERENCES}

[1] Wearesocial. (2016). Digital in 2016. [Online]. Available: http://wearesocial.com/uk/special-reports/digital-in-2016

[2] D. Kerpen and C. Kerpen, Likeable Social Media How to Delight Your Customers, Create an Irresistable Brand, and Be Amazing on Facebook, Twitter, LinkedIn, Instagram, Pinterest and More, McGraw- Hill, 2015.
[3] Moz. (2016). Beginners guide to social media. [Online]. Available: https://moz.com/beginners-guide-to-social-media/facebook

[4] P. Kotler and K. L. Keller, Marketing Management, 15th Global ed. Edinburgh Gate: Pearson Education Limited, 2016.

[5] D. Murthy, Twitter: Social Communication in the Twitter Age, Cambridge: Polity, 2013, pp. 7-8.

[6] J. H. Kietzmann, K. Hermkens, I. P. McCarthy, and B. S. Silvestre, "Social media? Get serious! Understanding the functional building blocks of social media," Business Horizons, vol. 54, pp. 241-251, 2011.

[7] C. Castronovo and L. Huang, "Social media in an alternative marketing communication model," Journal of Marketing Development and Competitiveness, vol. 6, no. 1, 2012.

[8] W. G. Mangold and D. J. Faulds, "Social media: The new hybrid element of the promotion mix," Business Horizons, vol. 52, pp. 357$365,2009$.

[9] D. Evans and J. KcKee, Social Media Marketing: The Next Generation of Business Engagement, Wiley Publishing, Inc., 2010.

[10] I. P. Cvijikj and F. Michahelles, "Online engagement factors on Facebook brand pages," Social Network Analysis and Mining, vol. 3, issue 4, pp. 843-861, 2013.

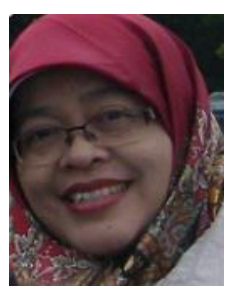

Indrawati was born in Indonesia and received her master degrees from Padjadjaran University (UNPAD), Indonesia, majoring in management. She received her Ph.D. in the Faculty of Management, Multimedia University (MMU) Malaysia. Indrawati's research interests include adoption of services based on technology, competitive intelligent, innovation, new product development, new product acceptance, creative industry, e-commerce, and smart city. She has published more than 300 articles in newspaper, tabloid, magazines, national (in Indonesia) and international proceedings and journals, as well as books. Several of her articles have got awards in several events, such as: the eight best articles on the 4th International Conference on E-Commerce with Focus on developing countries (ECDC), Kuala Lumpur Malaysia on 3-4 November, 2009, the best paper on smart collaborations for business in Technology and Information Industries (SCBTII) Conference, Bandung Indonesia August 15-16, 2016, and the best paper on International Seminar and Conference on Learning Organization (ISCLO) 2016, Bandung Indonesia, October 26, 2016.

Mamun Sumarna was born in Indonesia and received his bachelor of engineering degree from University of Indonesia, majoring in electrical engineering. He received his master degree in management from Telkom University, Indonesia. He is very interested in technology, business, and management. His career is as an information technology professional. He has experience in many industries, ranging from oil \& gas, manufacturing \& distribution, financial services, public services, telecommunication, and consulting business. His current position is as head of Business Solutions at a subsidiary company of PT Telekomunikasi Indonesia, Tbk. His activity is helping many organizations in designing and implementing digital technology solution. 